\title{
Petroleum Potential of Gombe Formation, Kolmani River-1 Well Gongola Basin, NE Nigeria
}

\author{
T. A. Adedosu ${ }^{1 *}$, S. A. Alao ${ }^{1}$, T.R. Ajayi ${ }^{2,3}$ and A. Akinlua ${ }^{4}$ \\ ${ }^{1}$ Department of Chemistry, Ladoke Akintola University of Technology, PMB 4000, \\ Ogbomoso Nigeria \\ ${ }^{2}$ Department of Geology, Obafemi Awolowo University, Ile-Ife, Nigeria. \\ ${ }^{3}$ Department of Geology, Osun State University Osogbo. \\ ${ }^{4}$ Fossil Fuels and Environmental Geochemistry Group, Department of Chemistry, Obafemi \\ Awolowo University, Ile-Ife, Nigeria \\ *Corresponding author: taadedosu@lautech.edu.ng; +2347055302824 \\ Received 28 February 2020; accepted 06 April 2020, published online 28 August 2020
}

\begin{abstract}
Gombe Formation is one of the promising potential source-rock of petroleum in the Gongola basin based on its appreciable amount of organic matter. The present study is therefore aimed at evaluating the hydrocarbon potential of Gombe Formation. Ditch-cutting samples were collected from the depth of $731.5 \mathrm{~m}$ to $1554.5 \mathrm{~m}$ from Gombe Formation that penetrated the Kolmani River-1 well. The source-rock potential was evaluated based on kerogen analysis and soluble organic matter content using Fourier Transform- Infra red spectroscopic (FT-IR) and Gas chromatography-Mass spectrometric (GC-MS) techniques respectively. There is presence of peak at $900-1000 \mathrm{~cm}^{-1}$ which is due to $\mathrm{CH}_{2}$ rocking vibration in long chain aliphatic substances, which is characteristic of liptinite macerals indicating good potential source-rock for oil and gas. The $n$-alkane ranges from $\mathrm{C}_{11}-\mathrm{C}_{33}$ maximizing at $n \mathrm{C}_{16}$ which suggests that the organic matter are majorly derived from marine organic matter. The $\mathrm{Pr} / \mathrm{Ph}$ (1.49-1.92) shows that the organic matter was deposited under sub-oxic condition. The distribution of hopanes, homohopanes $\left(\mathrm{C}_{27}-\mathrm{C}_{29}\right)$ steranes, $\left(\mathrm{C}_{0}-\mathrm{C}_{4}\right)$ alkylated naphthalenes and $\left(\mathrm{C}_{0}-\mathrm{C}_{3}\right)$ alkylated phenanthrenes indicate the presence of angiosperm, gymnosperm, algae, marine and bacteria input to the organic matter contained in the samples. Also the plot of DBT/P vs. $\mathrm{Pr} / \mathrm{Ph}$ classifies the samples into zone 3 (i.e. marine shale and other lacustrine). Various maturity parameters computed from saturate biomarker and polycyclic aromatic hydrocarbon distributions shows that the samples are low mature with the moderately mature zone at the bottom $(>1408.2 \mathrm{~m})$ of Gombe Formation. In conclusion, the kerogen was probably derived from type II/III organic matter capable of generating both oil and gas and the moderately mature zone lies at the bottom of the Formation.
\end{abstract}

Key words: Lacustrine, Gombe formation, Maturity, Hydrocarbon, Kerogen

\subsection{Introduction}

Gongola basin is the north-south trending of the Northern Benue Trough [1]. The structural history of this area commenced towards the beginning of the upper Cretaceous with the rifting of the Upper Benue Trough and the accumulation of considerable thickness of sediments in a number of depocentres within this NW-SE trending depression [2]. The Kolmani River-1 well (Fig. 1) is located at longitude $10{ }^{\circ} \mathrm{E}$ and latitude $10{ }^{\circ} \mathrm{N}$ in the Gongola Basin of the Upper Benue trough, Nigeria.The well penetrated four formations (Fig. 2) namely Gombe, Pindiga, Yolde and Bima Formations (Maastrichtian to Albian).The youngest Cretaceous sediment in the Gongola Basin is the coastal (deltaic) Gombe Sandstone, which unconformably 2.0 Sampling and experimental methods

Ditch-cuttings (14) were collected from Gombe Formation at various depths ranging covers the pre-mid-Santonian sequences in several places [4].

In the past, search for petroleum sourcerock in Gongola basin have been limited to Pindiga, Yolde and Bima formations [2, 5-8] probably based on the assumption that Gombe formation is relatively younger [4]. However, it was reported [8] that Gombe Formation has relatively high TOC (Table 1) which make it a good candidate to serve as potential source rock. The present study is to provide more information on the organic matter quality and thermal maturity of the shaly samples of Gombe Formation that were penetrated by Kolmani River -1 well in order to further assess its potential to serve as Petroleum source-rock in Gongola basin.

from $731.5 \mathrm{~m}-1408.2 \mathrm{~m}$. It was previously reported [8] that the samples from Gombe formation have high TOC and contain 
mixed/marine organic matter (Table 1). The samples were crushed or pulverized using mortar and pestle. It was dried at a temperature of $80^{\circ} \mathrm{C}$ in an oven and later packed with aluminium foil and kept in a dessicator to avoid moisture prior to use. For isolation of kerogen, $20 \mathrm{~mL}$ of $6 \mathrm{M}$ hydrochloric acid was added to $2 \mathrm{~g}$ of each sample in a digestion flask. This mixture was allowed to stand overnight ( 16 hours) at $60^{\circ} \mathrm{C}$. Then the mixture was filtered wash with hot distilled water, after the residue was dried in an oven at $60{ }^{\circ} \mathrm{C}$ for 4 hours. The dried residue was put into the flask and $10 \mathrm{~mL}$ of $49 \%$ hydrofluoric acid was added in a fume cupboard. The mixture was allowed to stand at $50{ }^{\circ} \mathrm{C}$ for 24 hours. Then saturated boric acid solution was added followed by $10 \mathrm{~mL}$ of $6 \mathrm{M}$ hydrochloric acid and the mixture was heated at $60{ }^{\circ} \mathrm{C}$ for 2 hours. The mixture was filtered and hot washed with distilled water; the residue was dried at room temperature. $20 \mathrm{~mL}$ of $3 \mathrm{M}$ $\mathrm{HNO}_{3}$ was added to dried residueand the mixture was heated at $45{ }^{\circ} \mathrm{C}$ for 1 hour. The mixture was filtered and hot washed with distilled water. The residue was dried at $60{ }^{\circ} \mathrm{C}$ for 2 hours. After, the samples were packed in aluminium foil and kept for infrared analysis.

$10 \mathrm{~g}$ of ditch cutting samples were ultrasonically treated sequentially with $20 \mathrm{~mL}$ of methanol, $20 \mathrm{~mL}$ of dichloromethane: methanol (1:1) and $20 \mathrm{~mL}$ of dichloromethane respectively for $20 \mathrm{~min}$ to extract the soluble organic matter (SOM). The extracts were fractionated on a silica - alumina column using hexane, hexane: dichloromethane (3:2) and methanol to elute saturate, aromatic and NSO fractions respectively. The solvent in the three fractions were concentrated using rotator evaporator to remove excess solvent and then transferred into a weighed clean vial and kept at $4{ }^{\circ} \mathrm{C}$ for GC-MS analysis.

Infra-red analysis of the isolated kerogen was carried out using $1 \mathrm{mg}$ of bulk powder sample (kerogen sample) added to $200 \mathrm{mg}$ of potassium bromide $(\mathrm{KBr})$ pellets and the mixture homogenized using a pestle in an agate mortar. Absorption spectra of the homogenized samples were collected using Fourier Transform infrared (FT - IR) Spectrometer (Nicolet Bench 505 p) with sample absorbance monitored using 256 scans with resolution of $4 \mathrm{~cm}^{-1}$ from a wave number of $4000-600 \mathrm{~cm}^{-1}$. Individual samples were analyzed for functional groups. The spectra were interpreted according to the following method [9]. The height of the peaks at approximately 1705 and $1605 \mathrm{~cm}^{-1}$ (corresponding to 1710 and $1630 \mathrm{~cm}^{-1}$ in the spectra of kerogen concentrate) and at 2930 and $2860 \mathrm{~cm}^{-1}$ were measured. The A-factor and $\mathrm{C}$-factor were calculated from the peak heights.

The saturate and aromatic hydrocarbon fractions were analyzed using a gas chromatography performed on a HewlettPackard 5973N mass spectrometer. The gas chromatography was equipped with a HP-5 fused silica capillary column $(30 \mathrm{~m} \times 0.25$ $\mathrm{mm}$, i.d., $0.25 \mu \mathrm{m}$ film thickness) and Helium was used as the carrier gas with flow rate of $1 \mathrm{ml} / \mathrm{min}$.

For saturate fractions, oven temperature was programmed from $80{ }^{\circ} \mathrm{C}$ for 2 minutes to $280{ }^{\circ} \mathrm{C}$ at the rate of $3{ }^{\circ} \mathrm{C} / \mathrm{min}^{-1}$, followed by an isothermal phase for 20 minutes at $280{ }^{\circ} \mathrm{C}$. The samples were analyzed in the full scan and SIM modes respectively. The SIM modes; $\mathrm{n}$ alkanes $(\mathrm{m} / \mathrm{z}=85)$, sesquiterpanes $(\mathrm{m} / \mathrm{z}=123)$, triterpanes $(\mathrm{m} / \mathrm{z}=191)$, and disasteranes and regular steranes $(\mathrm{m} / \mathrm{z}=218)$ were detected and individual compound were identified by the relative retention times and comparison of mass spectra with literature and library data. For aromatic fraction, the GC oven temperature was an isothermal of 2 minutes at temperature of $60^{\circ} \mathrm{C}$ and then programmed for $60{ }^{\circ} \mathrm{C}$ to $290{ }^{\circ} \mathrm{C}$ at the rate of $3{ }^{\circ} \mathrm{C} / \mathrm{min}^{-1}$ followed by isothermal phase of 20 minutes at $290{ }^{\circ} \mathrm{C}$. The samples were also analysed in full scan and SIM modes respectively. The SIM modes; naphthalene, methylnaphthalene, dimethylnaphthalene, trimethylnaphthalene, tetramethylnaphthalene and benzothiophene $(\mathrm{m} / \mathrm{z}=128, \quad 142, \quad 156, \quad 170$ and 184 respectively); phenanthrene, methylphenanthrene dimethyl phenanthrene and trimethyl phenanthrene $(\mathrm{m} / \mathrm{z}=178,192$, 208 and 220 respectively) were detected and the identification of individual aromatic compounds was made by relative retention time and comparison of mass spectra with literature and library data. the mass spectrometer was operated with electron energy impact of $70 \mathrm{eV}$ and an ion source temperature of $230{ }^{\circ} \mathrm{C}$. 


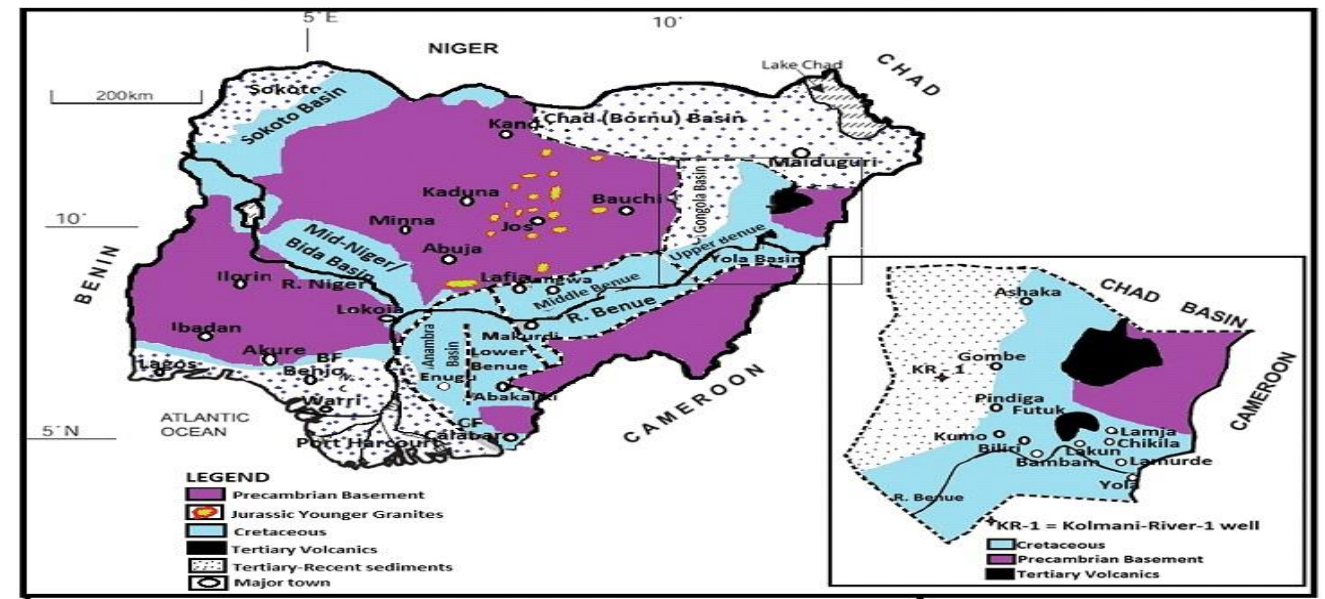

Fig. 1: This is a Geological map of Nigeria with an insert that shows the location of Kolmani River -1 well [4]

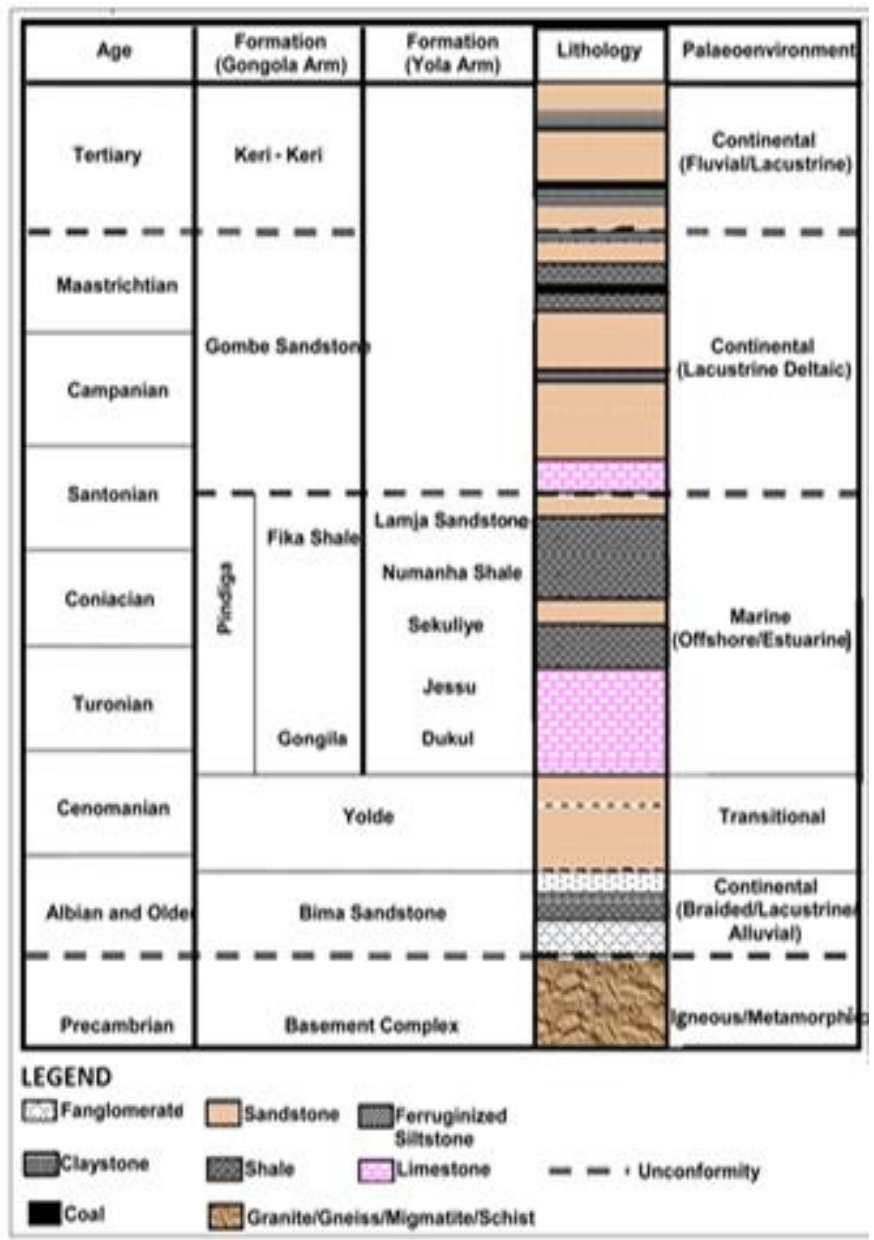

Fig. 2: Stratigraphic Section of Upper Benue Trough [10] 
Table 1: Total Organic Carbon (TOC) and Elemental Composition Ratios

\begin{tabular}{ccccccccc}
\hline Samples & $\begin{array}{c}\text { Depth } \\
(\mathbf{m})\end{array}$ & Lithology & $\begin{array}{c}\text { TOC } \\
(\mathbf{w t} \%)\end{array}$ & $\boldsymbol{\%} \mathbf{S}$ & TOC/S & TOC/N & S/C & C/N \\
\hline K1 & 731.5 & CS & 17.20 & 0.52 & 47.78 & 41.95 & 0.02 & 50.00 \\
K2 & 749.8 & CS & 6.17 & 0.32 & 33.35 & 34.28 & 0.03 & 33.30 \\
K3 & 823.0 & CS & 12.80 & 0.45 & 39.63 & 39.39 & 0.03 & 33.30 \\
K4 & 896.1 & CS & 5.47 & 0.27 & 30.39 & 29.57 & 0.03 & 33.30 \\
K5 & 969.30 & CS & 8.22 & 0.25 & 43.04 & 32.88 & 0.02 & 33.30 \\
K6 & 1042.0 & CS & 5.58 & 0.37 & 18.12 & 31.00 & 0.05 & 33.30 \\
K7 & 1115.6 & CS & 3.85 & 0.58 & 8.05 & 24.84 & 0.12 & 25.00 \\
K8 & 1188.7 & CS & 2.82 & 0.21 & 4.90 & 20.14 & 0.21 & 20.00 \\
K9 & 1261.8 & S & 0.86 & 1.22 & 1.11 & 9.05 & 0.89 & 9.10 \\
K10 & 1335.0 & S & 0.98 & 1.41 & 1.24 & 6.32 & 0.64 & 7.70 \\
K11 & 1344.2 & S & 0.80 & 0.98 & 1.32 & 8.42 & 0.66 & 10.00 \\
K12 & 1408.2 & S & 0.89 & 1.45 & 1.19 & 5.93 & 0.80 & 6.30 \\
K13 & 1481.3 & S & 0.71 & 1.35 & 1.05 & 4.73 & 0.94 & 4.8 \\
K14 & 1554.5 & S & 1.02 & 1.98 & 1.10 & 9.27 & 0.95 & 9.10 \\
\hline
\end{tabular}

\section{Reference-[8]}

\subsection{Results and discussion}

\subsection{Kerogen characterization}

The FT-IR spectra of the samples (Fig. 3) revealed strong aliphatic stretching bands in 2700-3000 $\mathrm{cm}^{-1}$ region, $\mathrm{CH}_{2}$ bands between $1365 \mathrm{~cm}^{-1}$ and $1447 \mathrm{~cm}^{-1}$ were also prominent indicating the substantial content of aliphatic structures. There are strong aromatic carbon $(\mathrm{C}=\mathrm{C})$ absorption in the range $1609-1638 \mathrm{~cm}^{-1}$. Also there is occurrence of $\mathrm{CH}$ bending of aromatic at $680 \mathrm{~cm}^{-1}-800 \mathrm{~cm}^{-1}$ as well as $\mathrm{C}=\mathrm{O}$ stretching bands of carboxyl/ester at $1718 \mathrm{~cm}^{-1}$ - $1750 \mathrm{~cm}^{-1}$. The peak intensities of the three major peaks used in calculating the $\mathrm{A}$ and $\mathrm{C}$ factors are given in (Table 2). Also the ratio $\mathrm{B} / \mathrm{F}$ calculated from the two major peaks,
$1609-1638 \mathrm{~cm}-1 \quad(\mathrm{C}=\mathrm{C})$ and $2923-2720 \mathrm{~cm}-1$ (C-H) are presented in (Table 2). All the studied samples were plotted along the type II/III (Fig. 4) evolution pathway indicating the organic matter contained in the Gombe Formation are formed from mixed/terrestrial materials and suggest that the source rocks are capable of generating both oil and gas $[9,11-$ 12]. The $\mathrm{B} / \mathrm{F}$ (ratio of aliphaticity to aromaticity) ranges from $0.98-1.00$ in all the samples. The $\mathrm{B} / \mathrm{F}$ ratio values indicate that aliphatic content in all the samples are high. Therefore the samples have the potential to generate both oil and gas [13].

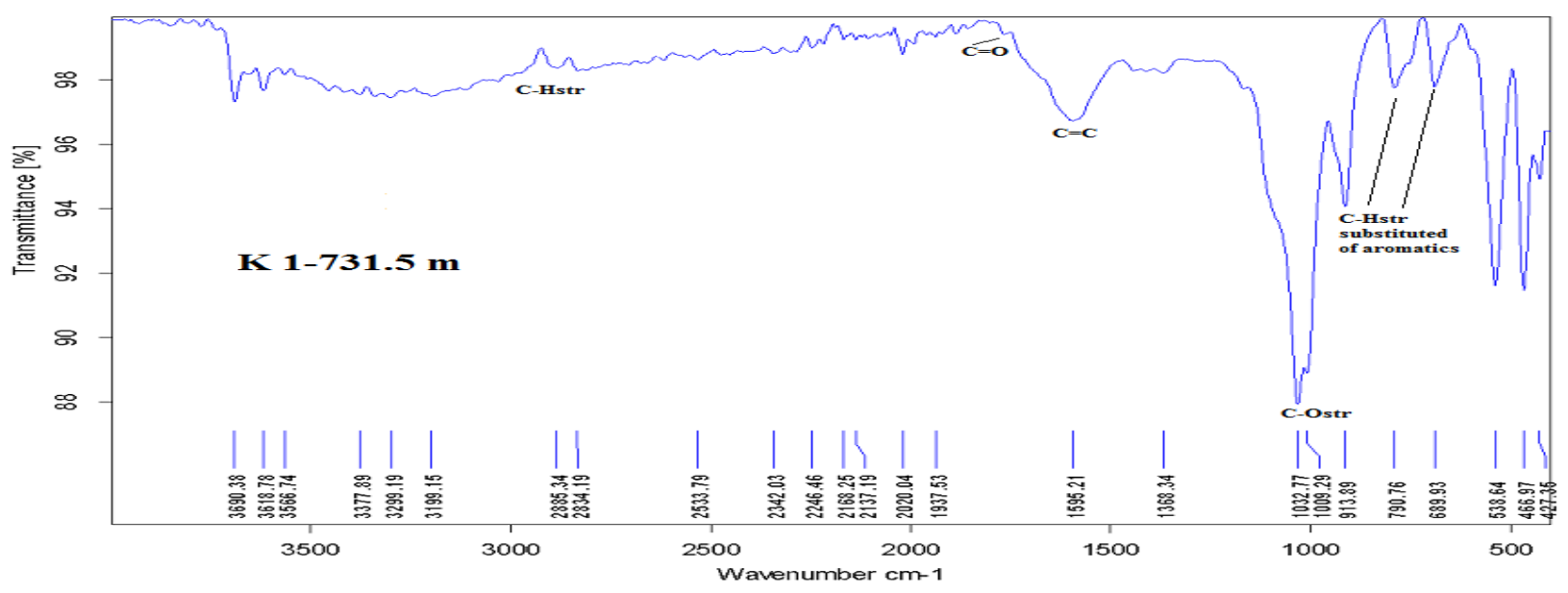

Fig. 3: IR spectra of the studied samples 
Table 2: A \& C-factors, B/F ratio obtained from the FT-IR spectra of the samples

\begin{tabular}{cccccc}
\hline Sample & Depth $(\mathbf{m})$ & A-factor & C-factor & Kerogen type & B/F ratio \\
\hline K1 & 731.5 & 0.6703 & 0.5044 & Type II/III & 0.9833 \\
K3 & 823.0 & 0.6674 & 0.5032 & Type II/III & 0.9947 \\
K5 & 969.3 & 0.6670 & 0.5018 & Type II/III & 0.9983 \\
K6 & 1042.0 & 0.6668 & 0.4995 & Type II/III & 0.9989 \\
K8 & 1188.7 & 0.6687 & 0.5023 & Type II/III & 1.0000 \\
K10 & 1335.0 & 0.6703 & 0.5037 & Type II/III & 0.9832 \\
K12 & 1408.2 & 0.6691 & 0.5035 & Type II/III & 0.9882 \\
\hline
\end{tabular}

$$
\begin{aligned}
& \text { A-Factor }=\frac{\left(2860+2930 \mathrm{~cm}^{-1}\right)}{\left(2860+2930+1630 \mathrm{~cm}^{-1}\right)} \\
& \text { C-Factor }=\frac{\left(1705 \mathrm{~cm}^{-1}\right)}{\left(1705+1630 \mathrm{~cm}^{-1}\right)}
\end{aligned}
$$

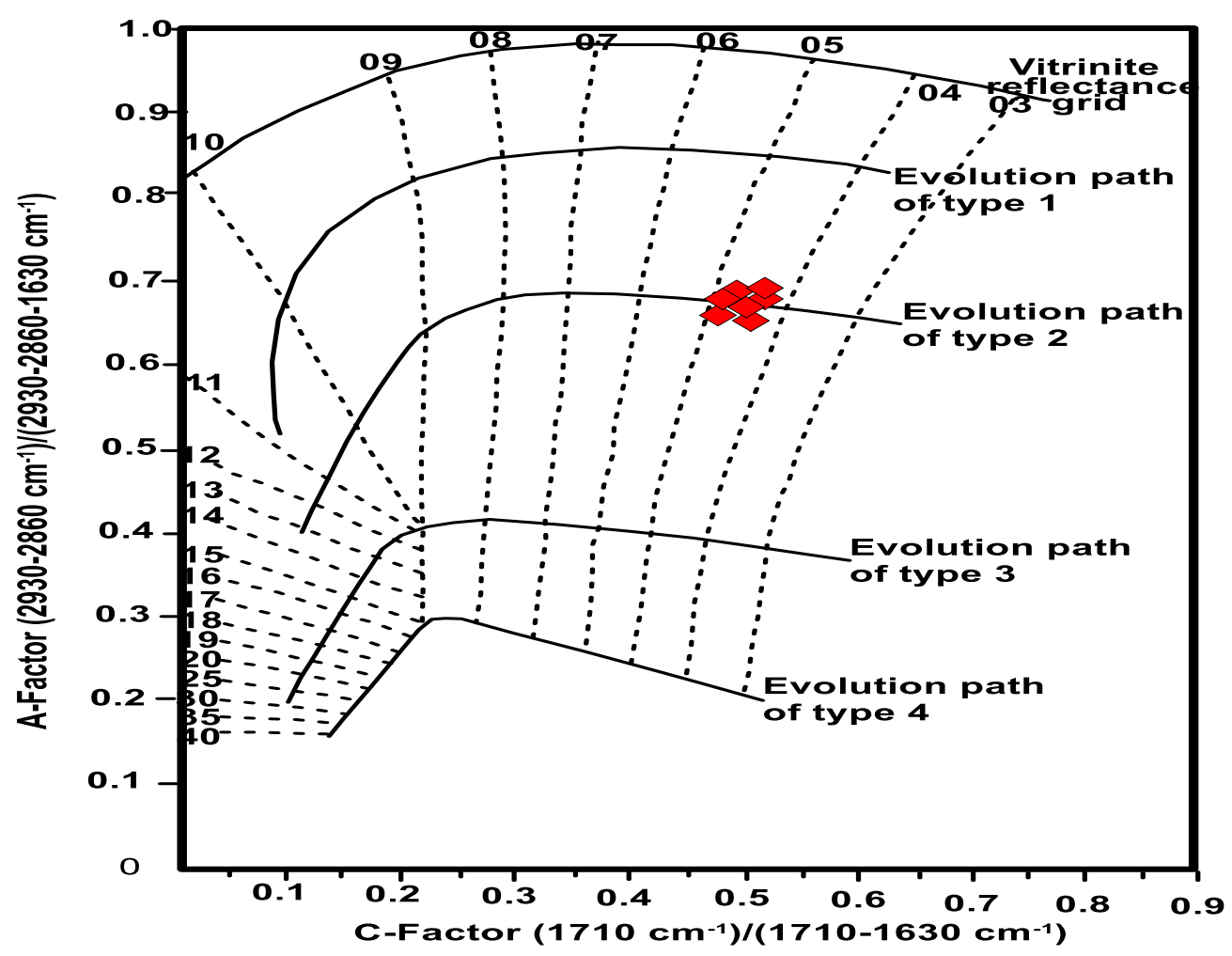

Fig. 4: Plot of A-factor and C-factor for kerogen typing

\section{2 n-Alkanes and Isoprenoids}

The n-alkane distribution in the samples ranges from $\mathrm{C}_{11}-\mathrm{C}_{31}$ in most samples maximizing at $\mathrm{C}_{16}$ (Fig. 5; Table 3). This pattern of distribution indicates organic matter mainly derived from marine settings [14]. $\mathrm{TAR}$ and $\mathrm{nC} 31 / \mathrm{nC} 19$ ration also ranges from 0.01 to 0.08 and 0.02 to 0.13 (Table 3) respectively supporting major contributions from phytoplankton to organic matter contained in the samples. The plots of $\operatorname{Pr} / n-C_{17}$ and $\mathrm{Ph} / \mathrm{n}-\mathrm{C}_{18}$ (Fig. 6) show that the samples have mixed terrestrial/marine source of organic matter [14]. The Carbon Preference Index (CPI) and Odd-Even Predominance (OEP) values (Table 3) range from 0.98-1.52 and 0.91-1.95 respectively. These values reflect low-marginal maturity status of the samples (Peters et al., 2005). The $\mathrm{Pr} / \mathrm{Ph}$ ratio ranged from 1.49-1.92 (Table 3), indicating sub-oxic depositional environment [14]. 


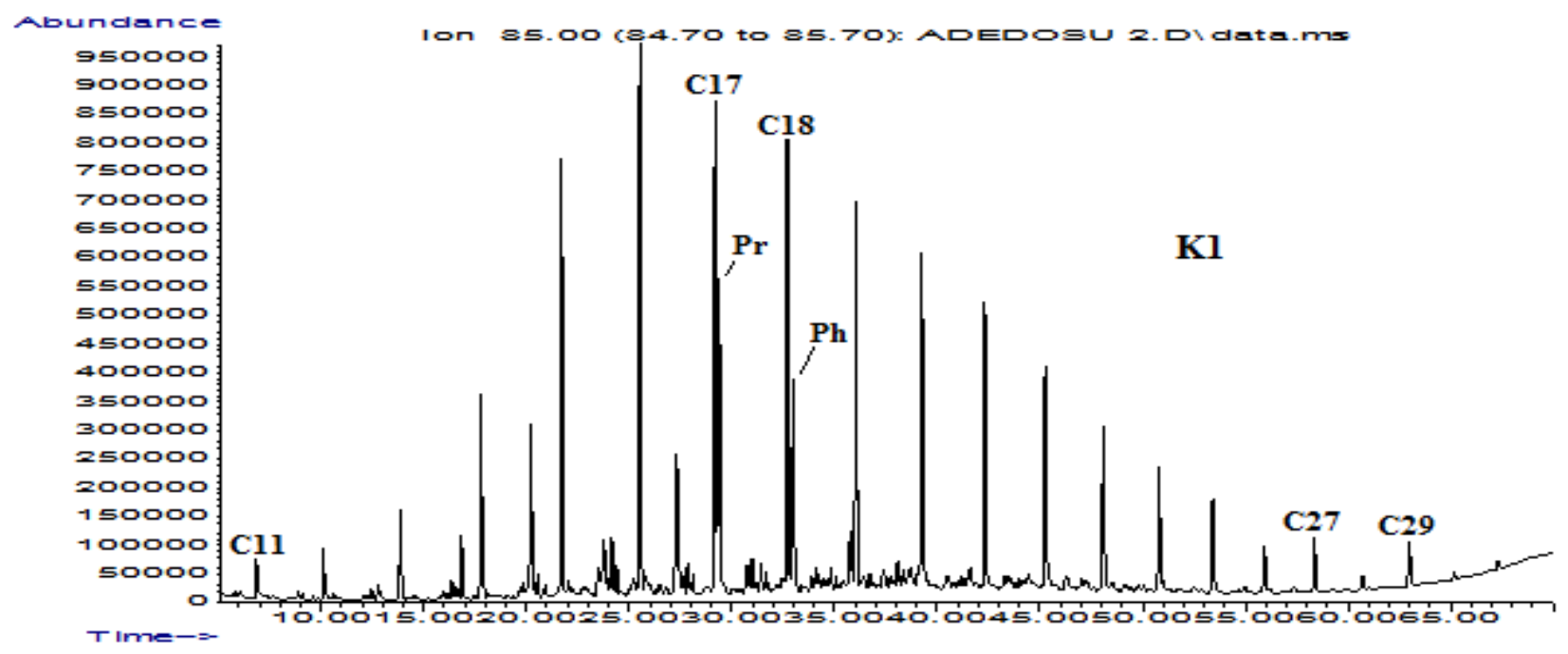

Fig. 5: $\mathrm{m} / \mathrm{z} 85$ showing the distributions of $n$-alkanes, pristane and phytane in the samples

Table 3: $N$-Alkane and Isoprenoid Parameters

\begin{tabular}{ccccccccccc}
\hline Sample & $\begin{array}{c}\text { Depth } \\
(\mathrm{m})\end{array}$ & $\mathrm{Pr} / \mathrm{Ph}$ & $\begin{array}{c}\mathrm{Pr} / \mathrm{nC} 1 \\
7\end{array}$ & $\mathrm{Ph} / \mathrm{nC} 18$ & $\begin{array}{c}\mathrm{nC} 31 / \mathrm{nC} 1 \\
9\end{array}$ & $\mathrm{TAR}$ & $\mathrm{CPI}(1)$ & OEP $(2)$ & $\begin{array}{c}\text { Cma } \\
\text { x }\end{array}$ & Crange \\
\hline $\mathrm{K} 1$ & 731.5 & 1.49 & 0.62 & 0.46 & 0.03 & 0.09 & 1.52 & 1.95 & $\mathrm{C} 16$ & $\mathrm{C} 11-\mathrm{C} 31$ \\
$\mathrm{~K} 3$ & 823.0 & 1.88 & 0.62 & 0.39 & 0.02 & 003 & 1.00 & 1.18 & $\mathrm{C} 16$ & $\mathrm{C} 11-\mathrm{C} 31$ \\
$\mathrm{~K} 5$ & 969.3 & 1.88 & 0.62 & 0.39 & 0.08 & 0.12 & 1.07 & 1.07 & $\mathrm{C} 16$ & $\mathrm{C} 11-\mathrm{C} 34$ \\
$\mathrm{~K} 6$ & 1042.0 & 1.82 & 0.63 & 0.40 & 0.06 & 0.13 & 1.34 & 1.93 & $\mathrm{C} 16$ & $\mathrm{C} 11-\mathrm{C} 32$ \\
$\mathrm{~K} 8$ & 1188.7 & 1.79 & 0.63 & 0.40 & 0.01 & 0.05 & 0.98 & 1.12 & $\mathrm{C} 16$ & $\mathrm{C} 11-\mathrm{C} 31$ \\
$\mathrm{~K} 10$ & 1335.0 & 1.78 & 0.61 & 0.40 & 0.01 & 0.03 & 0.98 & 1.00 & $\mathrm{C} 16$ & $\mathrm{C} 11-\mathrm{C} 31$ \\
$\mathrm{~K} 12$ & 1408.2 & 1.92 & 0.63 & 0.39 & 0.01 & 0.02 & 1.14 & 0.97 & $\mathrm{C} 16$ & $\mathrm{C} 11-\mathrm{C} 31$ \\
\hline
\end{tabular}

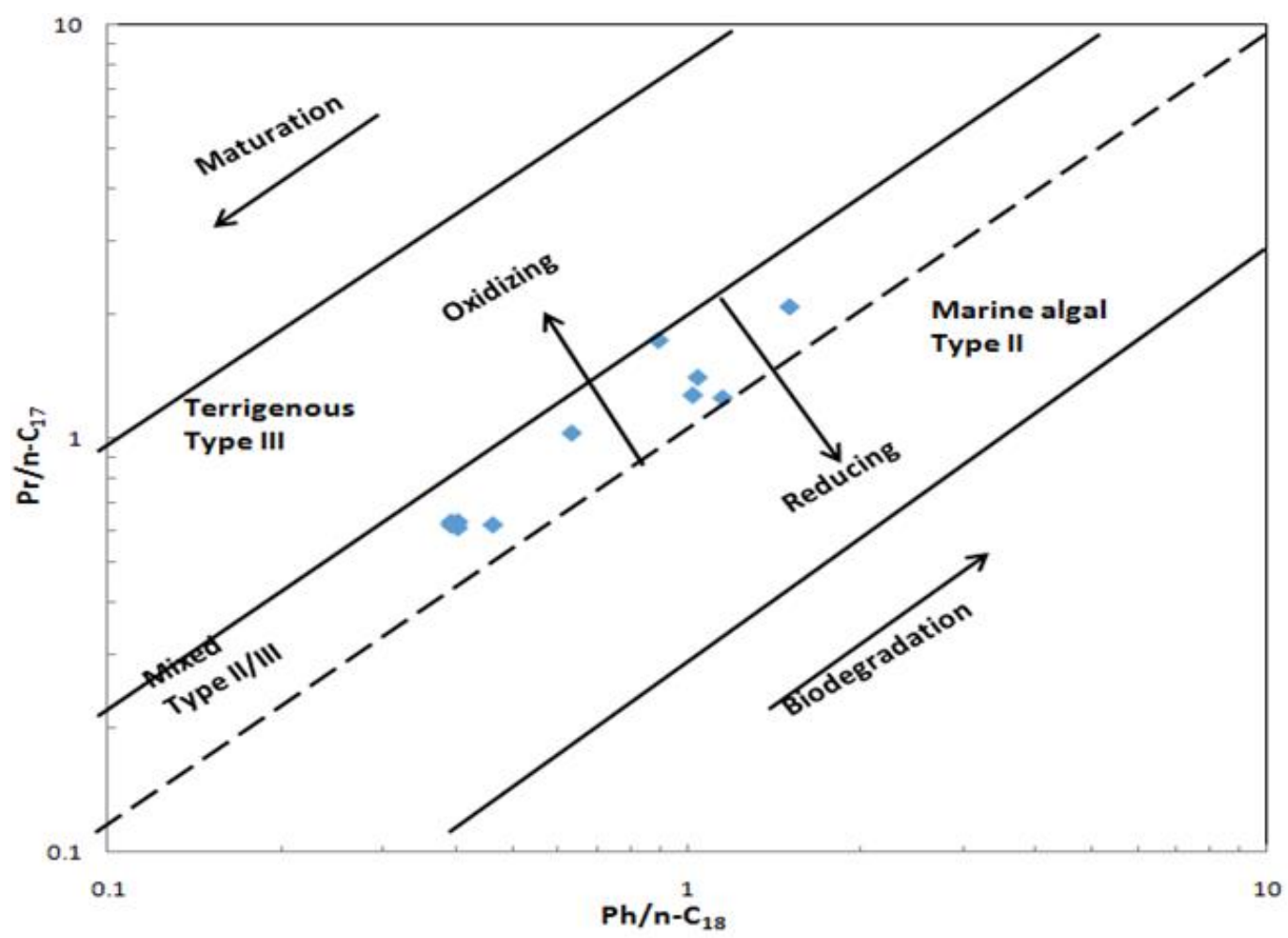

Figure 6: Kerogen typing and oxicity of depositional environment of the samples 


\subsection{Distribution of hopane and homohopanes}

$\mathrm{C}_{29}$ and $\mathrm{C}_{30} \alpha \beta$-hopane are present in appreciable amount in all the samples (Table 5), indicating significant contributions of prokaryotic organisms (i.e. bacteria, cyanobacteria and blue algae) to the source organic matter. A Sterane/hopane ratio is often used as a measure of relative inputs of eukaryotic versus prokaryotic debris [15]. Generally the values of sterane/hopane ratio (0.55-0.63) for the samples suggest incorporation of high level of bacteria inputs [15-17). $\quad \mathrm{C}_{31}$ and $\mathrm{C}_{32}$ homohopane isomerisation ratio rises from 0 to approximately 0.6 during maturation with the value ranging from $0.5-0.54$ indicates that a source rock is at the onset of oil generation [18]. The $\mathrm{C}_{32}$ homohopane ratio in the samples ranges from 0.48-0.62 (Table 5). The results from the studied samples indicated that the mature zone lie at the bottom of the Formation (i.e. K12) at depth of $1408 \mathrm{~m} \mathrm{[14,19-20].}$

Table 5: Source and Thermal Maturity Ratios based on Hopanes and Sterane

\begin{tabular}{|c|c|c|c|c|c|c|c|c|c|c|c|c|c|}
\hline Sample & $\begin{array}{l}\begin{array}{l}\text { Depth } \\
\text { (metre) }\end{array} \\
\text { (metre }\end{array}$ & $\begin{array}{c}\text { C29 } \\
\text { H/C3 } \\
\mathbf{0 H} \\
\end{array}$ & $\begin{array}{c}\mathbf{T s} / \mathbf{T} \\
\mathbf{m}\end{array}$ & $\begin{array}{c}\text { C31H } \\
\text { H } \\
(\mathrm{S} / \mathrm{S}+\mathrm{R} \\
) \\
\end{array}$ & $\begin{array}{c}\mathbf{C 3 2 H} \\
\mathbf{H} \\
(\mathbf{S} / \mathbf{S}+\mathbf{R} \\
) \\
\end{array}$ & $\mathbf{D} / \mathbf{S}$ & $\begin{array}{l}\mathrm{C} 27 \\
\text { /C2 } \\
9 \mathrm{~S} \\
\end{array}$ & $\mathbf{S} / \mathbf{H}$ & $\begin{array}{c}\% \mathrm{C2} \\
9 \mathrm{~S}\end{array}$ & $\begin{array}{c}\% \mathrm{C} 2 \\
8 \mathrm{~S}\end{array}$ & $\begin{array}{c}\% \mathrm{C} 2 \\
7 \mathrm{~S}\end{array}$ & $\begin{array}{c}20 \mathrm{~S} / \\
20 \mathrm{~S}+ \\
20 \mathrm{R}\end{array}$ & $\begin{array}{c}\beta \beta / \beta \\
\beta+\alpha \\
\alpha \\
\end{array}$ \\
\hline K1 & 731.5 & 1.37 & 0.15 & 0.24 & 0.48 & 4.31 & 0.56 & 0.57 & 55.90 & 12.90 & 31.20 & 0.62 & 0.31 \\
\hline K3 & 823.0 & 1.22 & 0.12 & 0.32 & 0.58 & 3.81 & 0.53 & 0.57 & 56.10 & 14.00 & 29.90 & 0.61 & 0.32 \\
\hline K5 & 969.3 & 1.17 & 0.16 & 0.32 & 0.59 & 3.34 & 0.52 & 0.63 & 49.50 & 24.60 & 25.90 & 0.62 & 0.31 \\
\hline K6 & 1042.0 & 1.31 & 0.16 & 0.32 & 0.56 & 3.49 & 0.53 & 0.56 & 56.10 & 14.30 & 29.70 & 0.62 & 0.31 \\
\hline K8 & 1188.7 & 1.21 & 0.16 & 0.31 & 0.56 & 3.32 & 0.55 & 0.55 & 55.80 & 13.90 & 30.40 & 0.61 & 0.30 \\
\hline K10 & 1335.0 & 1.17 & 0.14 & 0.31 & 0.56 & 2.98 & 0.54 & 0.57 & 56.20 & 13.80 & 30.00 & 0.62 & 0.30 \\
\hline K12 & 1408.2 & 1.38 & 0.14 & 0.32 & 0.62 & 3.46 & 0.54 & 0.59 & 56.00 & 14.00 & 30.00 & 0.61 & 0.31 \\
\hline
\end{tabular}

\subsection{Distribution of steranes}

The sterane distributions in the samples follows the order $\mathrm{C}_{29}>\mathrm{C}_{27}>\mathrm{C}_{28}$ (Table 5). Predominance of $\mathrm{C}_{29}$ over $\mathrm{C}_{27}$ sterane reflects a greater input of terrestrial relative to marine organic matter $[14,21]$. This is also reflected in the ratio of $\mathrm{C}_{27} / \mathrm{C}_{29}$ sterane which ranges from 0.52-0.56 (Table 5). An appreciable quantity of $\mathrm{C}_{27}$ and $\mathrm{C}_{28}$ in these samples also reflects contributions from phytoplankton, algae, diatoms, and dinoflagellates [14]. $\mathrm{C}_{29}$ steranes are considered to be terrestrial plant marker, however can be found in algae species while $\mathrm{C}_{28}$ steranes are regarded as both algae and terrestrial higher pants indicators and attributed to higher plants indicators while $\mathrm{C}_{27}$ steranes are indicator of zooplankton sources $[14,20]$. The distribution of steranes and diasteranes in the samples reflect mixed terrestrial and marine organic input. The sterane ternary plot (Fig. 7) indicates organic matter deposited in terrestrial to estuarine bay depositional environment [21]. The 20S/20S $+20 \mathrm{R}$ and $\alpha \beta \beta / \alpha \beta \beta+\alpha \alpha \alpha \mathrm{C} 29$ ratios range from 0.61 to 0.62 and 0.30 to 0.31 respectively (Table 5). These values show that the samples are low mature to marginally mature. 


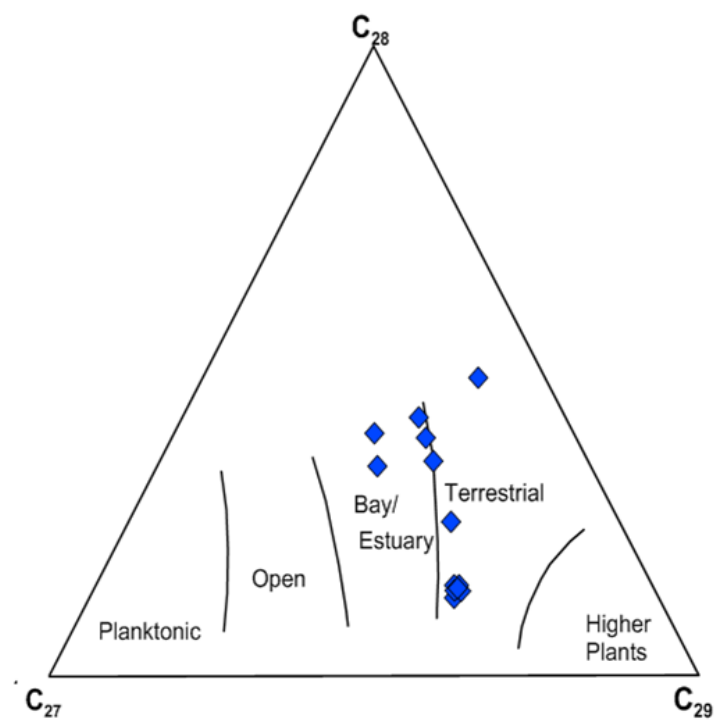

Figure 7: This is a C27-C28-C29 sterane ternary diagram showing depositional environment of the samples

\subsection{Polycyclic aromatic compounds}

The distributions of naphthalene and its alkyl derivatives as well as phenanthrene and its alkyl derivatives are shown in Fig. 8 and 9 respectively. The notable presence of 1,6-, 1,7-, and 2,6-dimethylnaphthalenes in samples depicts terrestrial organic matter contribution[22-23]. The possible biological precursors of 1,2,5-trimethylnaphthalene and $1,2,5,6$ tetramethylnaphthalene are $\beta$-amyrin and aromatic seco-hopanes, that are constituents of angiosperms [24]. Also their source has been related to gymnosperms [25]. 1,2,7-TMN has been related to angiosperm markers $[24,26]$. The notable presence of 1,2,5- and 1,2,7-trimethylnaphthalenes as well as 1,2,5,6-tetramethylnaphthalene in all the samples indicate contributions of both angiosperm and gymnosperm materials to the organic matter. Also, the occurrence of 1,2,6trimethylnaphthalene, $1,2,5,7-$ and 1,3,6,7tetramethylnaphthalenes in the samples indicate microbial input to the biomass [26].

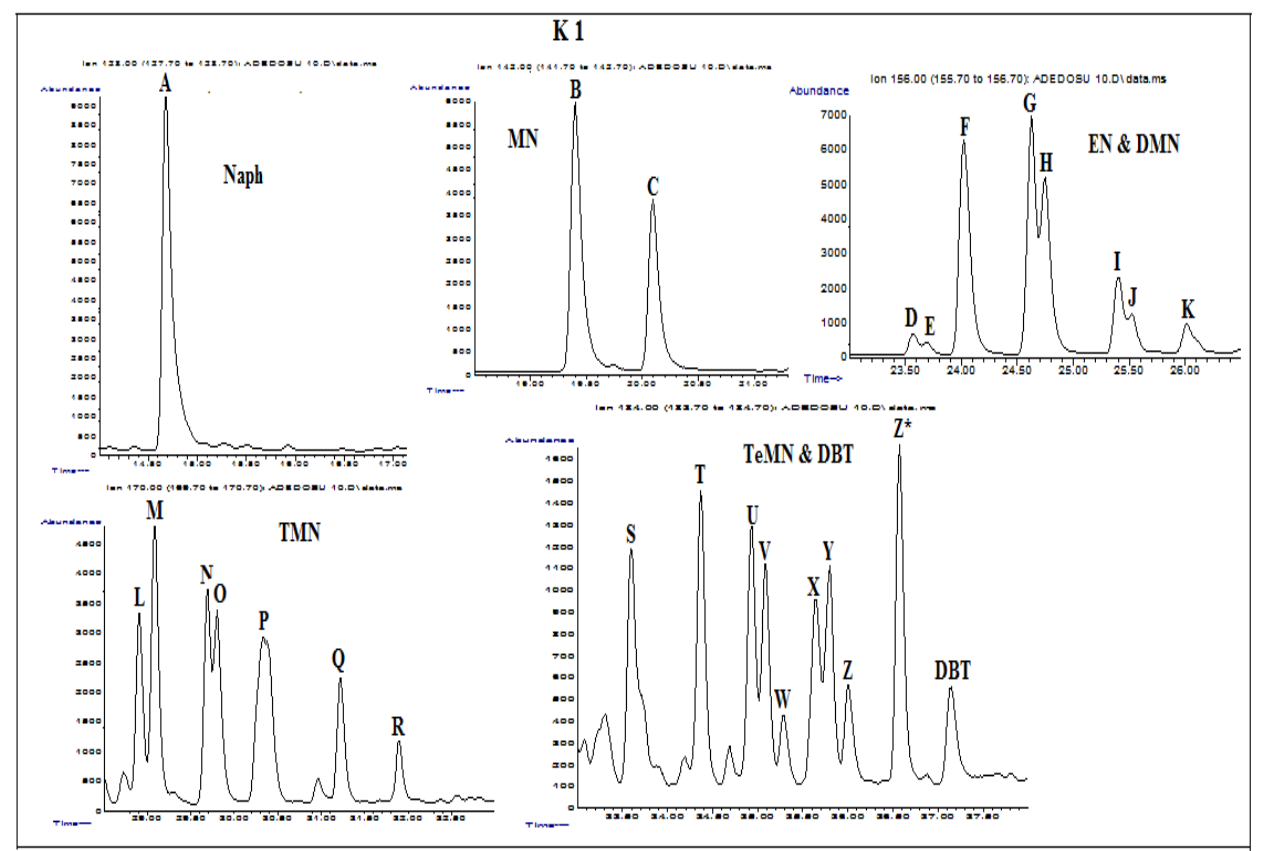

Fig. 8: The $m / z 128,142,156,170$ and 184 showing the distribution of naphthalene, methyl naphthalene, dimethyl naphthalene, trimethyl naphthalene, tetramethyl naphthaleneand dibenzothiophene in sample K1 
Table 6: Peak identities on $\mathbf{m} / \mathbf{z 1 2 8}, 142,156,170$ and 184 mass chromatograms.

\begin{tabular}{|c|c|c|}
\hline Peak & Abbreviation & Compound \\
\hline $\mathrm{A}$ & Naph & Naphthalene \\
\hline B & $1-\mathrm{MN}$ & 1-Methylnaphthalene \\
\hline $\mathrm{C}$ & 2-MN & 2-Methylnaphthalene \\
\hline $\mathrm{D}$ & 2-EN & 2-Ethylnaphthalene \\
\hline $\mathrm{E}$ & 1-EN & 1-Ethylnaphthalene \\
\hline $\mathrm{F}$ & $2,6+2,7-\mathrm{DMN}$ & 2,6 + 2,7-Dimethylnaphthalene \\
\hline $\mathrm{G}$ & $1,3+1,7-\mathrm{DMN}$ & 1,3 + 1,7-Dimethylnaphthalene \\
\hline $\mathrm{H}$ & 1,6-DMN & 1,6-Dimethylnaphthalene \\
\hline I & $2,3+1,4-\mathrm{DMN}$ & 2,3 + 1,4-Dimethylnaphthalene \\
\hline $\mathrm{J}$ & $1,5-\mathrm{DMN}$ & 1,5-Dimethylnaphthalene \\
\hline $\mathrm{K}$ & 1,2-DMN & 1,2-Dimethylnaphthalene \\
\hline $\mathrm{L}$ & $1,3,7-\mathrm{TMN}$ & 1,3,7-Trimethylnaphthalene \\
\hline M & $1,4,6+1,3,5-\mathrm{TMN}$ & $1,4,6+1,3,5$-Trimethylnaphthalene \\
\hline $\mathrm{N}$ & $2,3,6-\mathrm{TMN}$ & 2,3,6-Trimethylnaphthalene \\
\hline $\mathrm{O}$ & $1,2,7+1,6,7+1,2,6-\mathrm{TMN}$ & $1,2,7+1,6,7+1,2,6$-Trimethylnaphthalene \\
\hline $\mathrm{P}$ & $1,2,4-\mathrm{TMN}$ & 1,2,4-Trimethylnaphthalene \\
\hline $\mathrm{Q}$ & $1,2,5-\mathrm{TMN}$ & 1,2,5-Trimethylnaphthalene \\
\hline $\mathrm{R}$ & $1,3,5,7-\mathrm{TeMN}$ & 1,3,5,7-Tetramethylnaphthalene \\
\hline $\mathrm{S}$ & $1,3,6,7-\mathrm{TeMN}$ & 1,3,6,7-Tetramethylnaphthalene \\
\hline $\mathrm{T}$ & $1,2,4,6+1,2,4,7+1,4,6,7-\mathrm{TeMN}$ & $1,2,4,6+1,2,4,7+1,4,6,7$-Tetramethylnaphthalene \\
\hline $\mathrm{U}$ & $1,2,5,7-\mathrm{TeMN}$ & 1,2,5,7-Tetramethylnaphthalene \\
\hline $\mathrm{W}$ & $2,3,6,7-\mathrm{TeMN}$ & 2,3,6,7-Tetramethylnaphthalene \\
\hline $\mathrm{X}$ & $1,2,6,7-\mathrm{TeMN}$ & 1,2,6,7-Tetramethylnaphthalene \\
\hline $\mathrm{Y}$ & $1,2,3,7-\mathrm{TeMN}$ & $1,2,3,7$ - Tetramethylnaphthalene \\
\hline $\mathrm{Z}$ & $1,2,3,6-\mathrm{TeMN}$ & 1,2,3,6-Tetramethylnaphthalene \\
\hline \multirow[t]{2}{*}{$\mathrm{Z}^{*}$} & $1,2,5,6+1,2,3,5-\mathrm{TeMN}$ & $1,2,5,6+1,2,3,5$-Tetramethylnaphthalene \\
\hline & DBT & Dibenzothiophene \\
\hline
\end{tabular}

In all the samples, 9- methylphenanthrene (9-MP) predominates (Table 8) among the methylphenanthrenes indicating a presence of marine organic matter, though with a significant contribution from 1-MP, which is a terrestrial marker and also indicate lowmedium thermal maturity [27], consistent with the observation based on tetramethylnaphthalene ratio (TeMNr). The dimethylphenanthrenes (DMPs) are dominated by 1,3-, 3,9-, 2,10-, 3, 10-, 2,5-, 2,9- and 1,6DMP indicating presence of marine organic matter. On the other hand, notable presence of 1,7-DMP (pimanthrene) implies a significant contribution of terrestrial material [14]. Distribution of trimethylphenanthrenes (TMPs) also suggests mixed marine/terrestrial source due to substantial contribution of 1,3,7, 1,3,6- and 1,6,9-TMPs, as well as 1,2,6-TMP [14]. The presence of 1,2,8-TMP isomer could be related to bacterial, algal or terrestrial precursor material [14].

Low amount of dibenzothiophene to phenanthrene (DBT/P) ratio (0.11-0.19) (Table 8) indicates that organic matter is predominantly deposited in lacustrine or marine environment [28]. The cross plot of dibenzothiophene/phenanthrene (DBT/P) versus pristane/phytane in Fig.10 shows that organic matter of the studied samples plotted in zone 3 , representing marine shale and other lacustrine depositional environment.

Various maturity parameters calculated from the distributions of naphthalene and their alky derivatives (ENR and TeMNr) in samples presented in Table 8 range from 2.03-2.58 and 0.44-0.47 respectively. The alkylphenanthrene maturity ratios, MPR-1, MPI-1, MPI-1*and $\%$ RcMPI-1 range from 1.28-1.33, 0.67-0.75, $0.75-0.82$ and $0.80-0.85$ respectively. The values obtained indicating that the samples are low mature to early stage of oil window. 


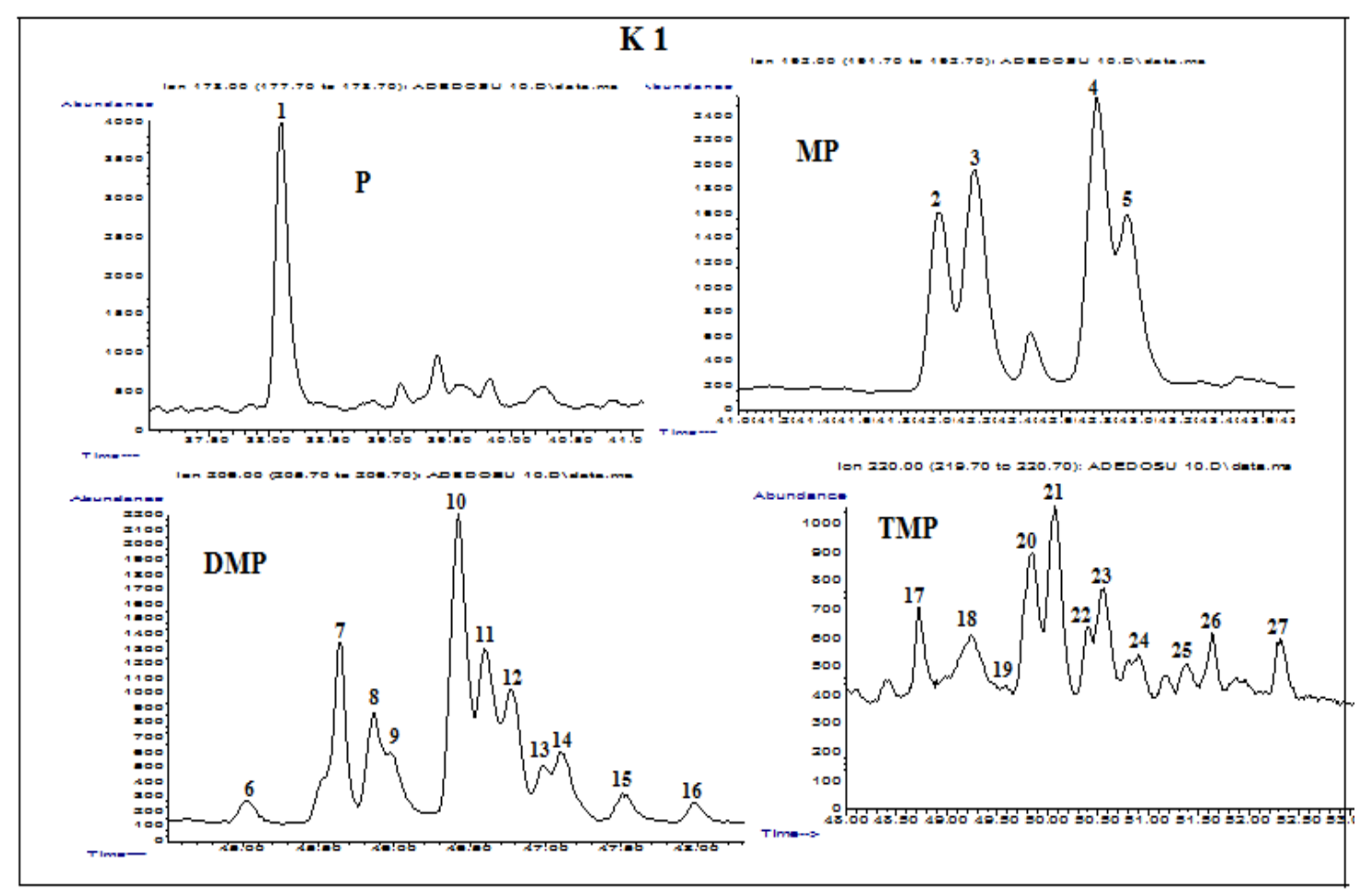

Fig. 9: The $\mathrm{m} / \mathrm{z} 178,192,208$ and 220 showing the distribution of phenanthrene methylphenanthrene, dimethylphenanthrene and trimethylphenanthrene in sample K1

Table 7: Peak identities on $\mathrm{m} / \mathrm{z}$ 178, 192, 208 and 220 mass chromatograms

\begin{tabular}{|c|c|}
\hline Peak & Compound \\
\hline 1 & Phenanthrene \\
\hline 2 & 3-Methylphenanthrene \\
\hline 3 & 2-Methylphenanthrene \\
\hline 4 & 9-Methylphenanthrene \\
\hline 5 & 1-Methylphenanthrene \\
\hline 6 & 3-Ethylphenanthrene \\
\hline 7 & 9-Ethylphenanthrene+ 1-Ethylphenanthrene+ 2-Ethylphenanthrene+3,6- \\
\hline 8 & Dimethylphenanthrene $3,5+2,6$-Dimethylphenanthrene \\
\hline 9 & 2,7-Dimethylphenanthrene \\
\hline 10 & $1,3+3,9+2,10+3,10$-Dimethylphenanthrene \\
\hline 11 & 2,5+2,9+1,6-Dimethylphenanthrene \\
\hline 12 & 1,7-Dimethylphenanthrene \\
\hline 13 & 2,3-Dimethylphenanthrene \\
\hline 14 & 1,9+4,9+4,10-Dimethylphenanthrene \\
\hline 15 & 1,8-Dimethylphenanthrene \\
\hline 16 & 1,2-Dimethylphenanthrene \\
\hline 17 & $1,3,6+1,3,10+2,6,10$-Trimethylphenanthrene \\
\hline 18 & $1,3,7+2,6,9+2,7,9$-Trimethylphenanthrene \\
\hline 19 & 1,3,9+2,3,6-Trimethylphenanthrene \\
\hline 20 & $1,6,9+1,7,9+2,3,7-$ Triimethylphenanthrene \\
\hline 21 & 1,3,8-Trimethylphenanthrene \\
\hline 22 & 2,3,10-Triimethylphenanthrene \\
\hline 23 & UNKNOWN \\
\hline 24 & 1,6,7-Trimethylphenanthrene \\
\hline 25 & 1,2,6- Trimethylphenanthrene \\
\hline 26 & 1,2,7-Trimethylphenanthrene \\
\hline 27 & 1,2,8-Trimethylphenanthrene \\
\hline
\end{tabular}


Table 8: Source and Thermal Maturity Ratios based on Aromatic compounds

\begin{tabular}{cccccccccc}
\hline \multirow{2}{*}{ Sample } & Depth(m) & $\begin{array}{c}\text { MP/9- } \\
\text { MP }\end{array}$ & DBT/P & $\begin{array}{c}\text { MPR- } \\
\mathbf{1}\end{array}$ & $\begin{array}{c}\text { MPI- } \\
\mathbf{1}\end{array}$ & $\begin{array}{c}\text { MPI- } \\
\mathbf{1} *\end{array}$ & $\begin{array}{l}\text { \%RcMPI- } \\
\mathbf{1}\end{array}$ & ENR & TeMNr \\
\hline K1 & 731.5 & 0.59 & 0.11 & 1.28 & 0.69 & 0.76 & 0.8 & 2.36 & 0.44 \\
K6 & 1042.0 & 0.59 & 0.13 & 1.31 & 0.67 & 0.75 & 0.8 & 2.03 & 0.45 \\
K12 & 1408.2 & 0.6 & 0.19 & 1.33 & 0.75 & 0.82 & 0.85 & 2.58 & 0.47 \\
\hline
\end{tabular}

$\mathrm{ENR}=2-\mathrm{EN} / 1-\mathrm{EN} ; \quad \mathrm{MPR}-1=2-\mathrm{MP} / 1-\mathrm{MP} ; \quad \mathrm{MPI}-1=1.5[2-\mathrm{MP}+3-\mathrm{MP}] / 0.69[\mathrm{P}+1-\mathrm{MP}+9-\mathrm{MP}] ; \quad \mathrm{MPI}-$ $1^{*}=1.89[2-\mathrm{MP}+3-\mathrm{MP}] / \mathrm{P}+1.26[1-\mathrm{MP}+9-\mathrm{MP}] ; \% \mathrm{R}_{\mathrm{C}} \mathrm{MPI}=0.6[\mathrm{MPI}-1]+0.4 ; \quad \mathrm{TeMNR}=1,3,6,7-$ TeMN/ $[1,3,6,7+1,2,5,6+1,2,3,5-] \mathrm{TeMN}$

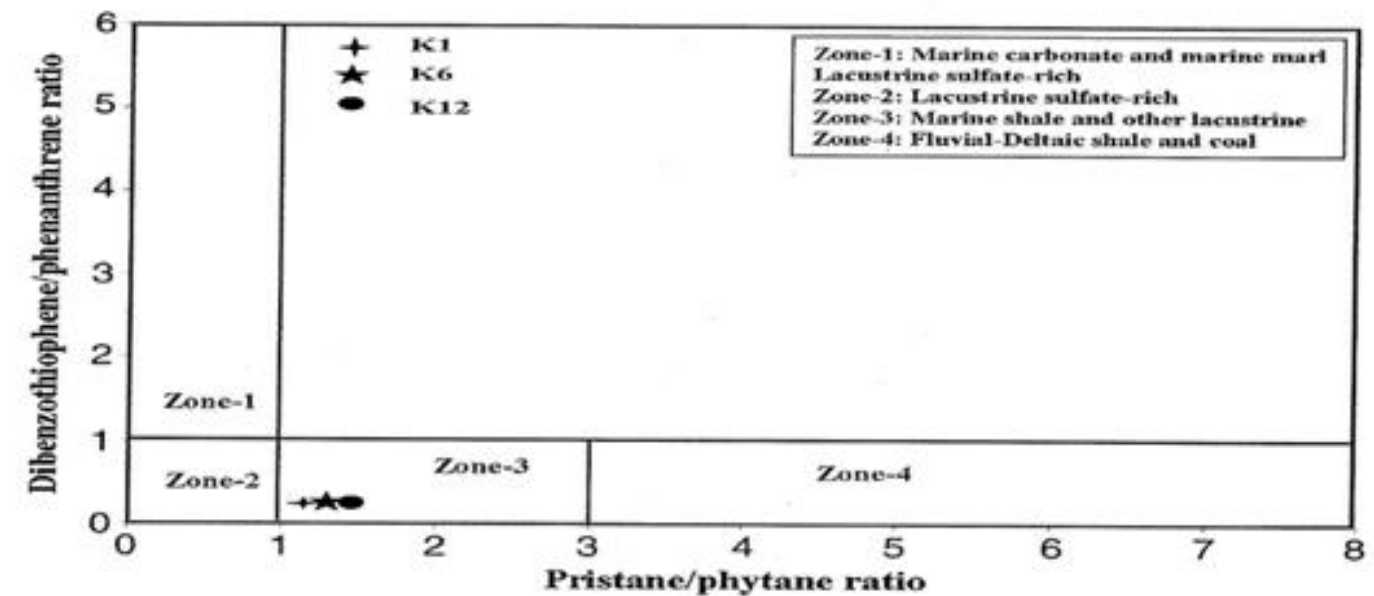

Fig. 10: Cross plot of dibenzothiophene/phenanthrene (DBT/P) vs Pristane/Phytane (Pr/Ph) of the samples

\section{Conclusion}

All the samples were plotted along the type II/III evolution pathway indicated that the organic matter contained in the samples are formed from both terrestrial and marine settings and suggest that the source rocks are capable of generating both oil and gas. The $\mathrm{B} / \mathrm{F}$ ratio values $(0.98-1.00)$ indicated that aliphatic content in all the samples are high hence, suggests that samples have potential to generate oil and gas.

The n-alkane distributions in the samples range from $\mathrm{C}_{11}-\mathrm{C}_{32}$ maximizing at $\mathrm{C}_{16}, \mathrm{Pr} / \mathrm{Ph}$ ratio (1.49-1.92), there is abundant hopanes, homohopanes and predominant $\mathrm{C}_{28}, \mathrm{C}_{29}$ regular and rearranged steranes. These indicated a significant contribution of prokaryotic organisms to the source of organic matter and also showed that the organic matter contained in the samples has mixed marine/terrestrial input.

The notable presence of 1,2,5-, 1,2,6-, and 1,2,7-trimethylnaphthalenes, as well as 1,2,5,6-, $\quad 1,2,5,7-, \quad 1,3,6,7-$ tetramethylnaphthalenes in the samples indicate angiosperm, gymnosperms and microbial input. The predominance of 9methylphenanthrene depicts presence of marine organic matter, while the occurrence of 1,2,8-trimethylphenanthrene reflects contribution from bacteria, algal or terrestrial materials.

The cross plot of dibenzothiophene/phenanthrene (DBT/P) versus pristane/phytane shown that organic matter of the studied samples was plotted in zone 3, representing marine shale and lacustrine depositional environment.

Various maturity parameters computed from biomarkers and polyaromatic hydrocarbon show that the lower part of Gombe formation is low-mature.However, moderately mature zone can be found at the bottom of the formation and therefore can serve as a potential source-rock in Kolmani River-1.

\section{References}

1. M. B. Abubakar, H.P. Luterbacher, A. R. Ashraf, R. Ziedner and A.S. Maigari (2011), 
Late Cretaceous palynostratigraphy in the Gongola Basin (Upper Benue Trough, Nigeria), Journal of African Earth Sciences, 60, 19-27.

2. E.E. Epuh, D. O. Olorode and P. C. Nwilo (2012a), Analysis of Gongola Basin Depositional Sequence using Seismic Stratigraphy, Journal of Pure and Applied Science and Technology, 2 (2), 9-21.

3. J. Benkhelil (1989), The evolution of the Cretaceous Benue Trough, Nigeria, Journal of African Earth Sciences, 8, 251-282.

4. M. B. Abubakar, N.G. Obaje, H.P. Luterbacher, E.F.C. Dike and A.R. Ashraf (2006), A report on the occurrence of AlbianCenomanian elater-bearing pollen in Nasara-1 well, Upper Benue Trough, Nigeria: Biostratigraphic and palaeoclimatological implications, Journal of African Earth Sciences 45, 347- 354.

5. N. G. Obaje, H. Wehner, G. Scheeder, M.B. Abubakar and A. Jauro (2004), Hydrocarbon prospectivity of Nigeria's inland basins: From the viewpoint of organic geochemistry and organic petrology, AAPG Bulletin, 87, 325353.

6. M. B. Abubakar, E. F. C. Dike, N.G. Obaje, H. Wehner and A. Jauro (2008), Petroleum Prospectivity of Cretaceous Formations in the Gongola Basin, Upper Benue Trough, Nigeria: An Organic Geochemical Perspective on a Migrated Oil Controversy, Journal of Petroleum Geology, 31(4), 387-408.

7. E. E. Epuh, D. O. Olorode, P.C. Nwilo and C. U, Ezeigbo (2012b), Petrophysical Characterization of Gongola Basin (Kolmani River -1) Shaly-Sand Reservoir Using Dual Water Model, Journal of Asian Scientific Research, 2(4), 170-181.

8. T.A. Adedosu, T.R. Ajayi, X. Yongqiang, Y. Li, F. Chenchen, Y. Chen and A. Akinlua (2014), Geochemical evaluation of Kolmani River-1 well, Gongola Basin, Upper Benue Trough, Nigeria, NAPE Bulletin, 26, 1- 51.

9. H. W. Ganz, and W. Kalkreuth (1987), Application of infrared Spectroscopy to the classification of kerogen-types and the evaluation of source rock and oil shale potential, Fuel, 66, 708-711.

10. S.O. Akande, O.J. Ojo, B.D. Erdtmann and M. Hetenyi (1998), Paleoenvironments, source rock potential and thermal maturity of the Upper Benue rift basins, Nigeria: implications for hydrocarbon exploration, Organic Geochemistry, 29 (1-3), 531-542.

11. T. A. Adedosu and O.O. Sonibare (2005), Characterization of Niger Delta crude oil by Infrared Spectroscopy, Journal of Applied Sciences, 5, 906-909.

12. T. A. Adedosu and H.O. Adedosu (2008), Application of Fourier Transform Infrared Spectroscopy for the Preliminary Assessments of

Hydrocarbon Potential of Coals from Benue Trough, Nigeria, Science Focus, 13(1), 51-60.

13. T. A. Adedosu, H.O. Adedosu and F.M. Adebiyi (2007), Geochemical and Mineralogical Significance of Trace Metals in Benue Trough coal, Nigeria, Journal of Applied Science 7(20), 3101-3105.

14. Peters, K.E., Walters, C.C., Moldowan, J.M. (2005), The Biomarker Guide. Biomarkers and Isotopes in Petroleum Exploration and Earth History, 2. Cambridge University Press, UK.

15. K.E. Peters and J. M. Moldowan (1993), The Biomarker Guide, Englewood Cliffs, NJ, Prentice Hall, 363.

16. B.P. Tissot and D. H. Welte (1984), Petroleum formation and occurrence: New York, Springer-Verlag, 699.

17. C.M. Norgate, C. J., Boreham and A.J. Wilkens (1999), Changes in hydrocarbon maturity indices with coal rank and type, Buller Coalfield, New Zealand, Organic Geochemistry, 30,985-1010.

18. W.K. Seifert and J.M. Moldowan (1980), The effect of thermal stress on source-rock quality as measured by hopane stereochemistry, Phys. Chem. Earth, 12, 229237. 
19. T.A. Adedosu, O.O. Sonibare, O. Ekundayo and J. Tuo (2010), HydrocarbonGenerative Potential of Coal and Interbedded Shale of Mamu Formation, Benue Trough, Nigeria, Petroleum Science and Technology, 28, 4: 412-427.

20. T.A. Adedosu, O.O. Sonibare, J. Tuo and O. Ekundayo (2012), Biomarkers, carbon isotopic composition and source rock potentials of Awgu coals, middle Benue trough, Nigeria, Journal of African Earth Sciences, 66-67,13-21.

21. M.L.N. Kagya (1996), Geochemical characterization of Triassic petroleum source rock in the Mandawa basin, Tanzania, $J$. Afr. Earth Sci. 23,73-88.

22. M. Asif and T. Fazeelat (2007), Distribution and geochemical applications of aromatic hydrocarbons in crude oils, J. Res. Sci., 18, 79-90.

23. T.A. Adedosu, O.O. Sonibare, J. Tuo and O. Ekundayo (2011), Aromatic hydrocarbons distribution in Nigerian coal and their geochemical significance, Energy Sources,

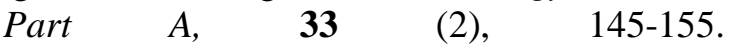

24. M.G. Strachan, R. Alexander and R. Kagi (1988), Trimethylnaphtalene in crude oils and sediments: Effect of source and maturity, Geochimica et Cosmochimica Acta, 52, 12551264.

25. A. Armstroff, H. Wilkes, J. Schwarzbauer, R. Littke and B. Horsfield (2006), Aromatic hydrocarbon biomarkers in terrestrial organic matter of Devonian to Permian age, Palaeogeog. Palaeoclimatol. Palaeoecol., 240, 253-274.

26. M. Asif and T. Fazeelat (2012), Petroleum geochemistry of the Potwar Basin, Pakistan: II - Oil classification based on heterocyclic and polycyclic aromatic hydrocarbons, Appl. Geochem., 27, 1655-1665.

27. H. Budzinski, P. Garrigues, J. Connan, J. Devillers, D. Domine, M. Radke and J.L. Oudin (1995), Alkylated phenanthrene distributions as maturity and origin indicators in crude oils and rock extracts, Geochimica et Cosmochimica Acta, 59, 2043-2056.

28. W.B. Hughes, A.G. Holba and L.I.P. Dzhou (1995), The ratios of dibenzothiophene to phenanthrene and pristane to phytane as indicators of depositional environment and lithology of petroleum source rocks, Geochemica et Cosmochimica Acta, 59, 35813598. 